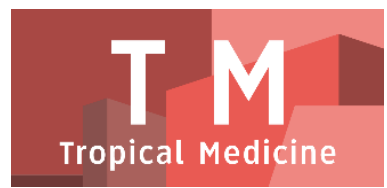

PAPER - OPEN ACCESS

\title{
Pemeriksaan Flavonoid dan Polifenol serta Uji Aktivitas Antioksidan Teh Daun Sirsak Kemasan (Annona Muricata Linn.) dengan Metode Dpph.
}

Author : Chinty Indria Mentari

DOI $\quad: 10.32734 /$ tm.v1i1.76

Paper Page : $277-283$

Volume 1 Issue 1 - 2018 TALENTA Conference Series: Tropical Medicine (TM)

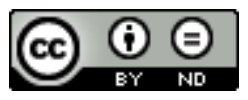

This work is licensed under a Creative Commons Attribution-NoDerivatives 4.0 International License.

Published under licence by TALENTA Publisher, Universitas Sumatera Utara
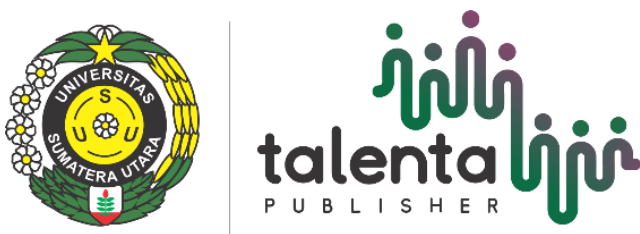


\title{
Pemeriksaan Flavonoid dan Polifenol serta Uji Aktivitas Antioksidan Teh Daun Sirsak Kemasan (Annona Muricata Linn.) dengan Metode Dpph.
}

\author{
Chinty Indria Mentari ${ }^{\mathrm{a}}$, Sudarmi ${ }^{\mathrm{b}}$ dan Fathur Rahman Harun ${ }^{\mathrm{a}}$ \\ ${ }^{a}$ Fakultas Farmasi, Universitas Sumatera Utara 20155, Indonesia \\ ${ }^{b}$ Laboratorium Penelitian, Universitas Sumatera Utara 20155, Indonesia
}

Sainttari@gmail.com

\begin{abstract}
Abstrak
Antioksidan berguna bagi kesehatan yakni untuk melindungi dan mengobati tubuh dari berbagai macam penyakit degeneratif dan kanker yang disebabkan oleh radikal bebas dengan cara menetralkannya. Salah satu tanaman yang dimanfaatkan sebagai antioksidan adalah daun sirsak (Annona muricata Linn.). Masyarakat Indonesia menggunakan daun sirsak secara tradisional sebagai minuman fungsional yang dapat difungsikan antara lain sebagai obat herbal, namun bentuk teh daun sirsak kemasan belum banyak digunakan oleh masyarakat. Karena itu perlu dilakukan kajian tentang aktivitas antioksidan dalam teh daun sirsak, untuk menggali potensi daun sirsak sebagai minuman fungsional yang dapat difungsikan antara lain sebagai obat herbal. Penelitian ini melakukan pemeriksaan senyawa flavonoid dan polifenol yang berperan sebagai antioksidan dan mengukur aktivitas antioksidan pada ketiga sediaan teh daun sirsak kemasan menggunakan metode pemerangkapan radikal bebas DPPH (1,1-diphenyl-2- picrylhydrazil), diukur pada panjang gelombang maksimum $516 \mathrm{~nm}$ setelah 60 menit pada suhu kamar. Hasil pemeriksaan sediaan teh daun sirsak kemasan memberikan hasil positif terhadap golongan senyawa flavonoid dan polifenol serta hasil aktivitas antioksidan dalam memerangkap radikal bebas DPPH diperoleh nilai Inhibitory Concentration (IC50) masing-masing STDSK pada K1: 1943 ppm, K2: 2287 ppm, dan K3 sebesar 2383 ppm. Diperoleh kesimpulan dari penelitian ini adalah masing-masing seduhan teh daun sirsak kemasan menunjukkan aktivitas antioksidan dalam kategori sangat lemah.
\end{abstract}

Kata Kunci: Antioksidan; DPPH; Seduhan teh daun sirsak kemasan (STDSK);

\section{Pendahuluan}

\subsection{Latar Belakang}

Antioksidan merupakan suatu zat yang dapat menetralkan radikal bebas sehingga melindungi tubuh dari berbagai macam penyakit dengan cara mengikat radikal bebas dan molekul yang sangat reaktif yang dapat merusak sel (Winarsi, 2007). Radikal bebas adalah sekelompok bahan kimia baik berupa atom maupun molekul yang memiliki elektron tidak berpasangan pada lapisan luarnya atau kehilangan elektron (Werdhasari, 2014). Radikal bebas merupakan salah satu faktor penyebab kanker dan penyakit degeneratif lain (Salamah, 2015). Mekanisme perusakan sel oleh radikal bebas berawal dari teroksidasinya asam lemak tak jenuh pada lapisan lipid membran 
sel, reaksi ini mengawali terjadinya oksidasi lipid berantai yang menyebabkan kerusakan membran sel, oksidasi lebih jauh akan terjadi pada protein yang berakibat fatal dengan rusaknya DNA. Diperkirakan sebagian penyakit yang disebutkan di atas diawali oleh proses perusakan ini (Cook and Samman, 1996).

Sebenarnya tubuh mempunyai sistem antioksidan termasuk superoksid dismutase, katalase, dan glutation akan tetapi jika terjadi paparan oksidan yang berlebihan antioksidan tubuh ini tidak akan mampu mengatasinya, sehingga tubuh memerlukan antioksidan dari luar yang diperoleh dari makanan maupun minuman (Nordmann, 1993).

Antioksidan dikelompokkan menjadi dua kelompok yaitu antioksidan sintetik (Buatan) dan antioksidan alami. Senyawa antioksidan yang berasal dari bahan-bahan alami mendapat perhatian yang sangat besar, hal ini disebabkan atas Dasar penggunaan yang aman dibandingkan dengan antioksidan sintetik (Julyasih, et al., 2009). Antioksidan sintetik berpotensi sebagai karsinogenik terhadap efek reproduksi dan metabolisme (Hernani, 2005).

Salah satu tanaman yang dapat dimanfaatkan sebagai antioksidan adalah sirsak (Annona Muricata L.) (Budiarti, et al., 2014). Bagian tanaman sirsak yang memiliki jumlah besar dalam satu pohon adalah daunnya. Daun sirsak mengandung senyawa bioaktif seperti tanin, flavonoid, polifenol, Annonaceous acetogenius dan saponin. (Handayani, 2016). Senyawa flavonoid dan polifenol merupakan senyawa yang berpotensi sebagai antioksidan (Salamah, 2015).

Masyarakat Indonesia menggunakan daun sirsak secara tradisional sebagai minuman fungsional yang dapat difungsikan antara lain sebagai obat herbal, yaitu dengan cara meminum air rebusan daun sirsak segar (Adri dan Wikanastri, 2013). Meskipun air rebusan daun sirsak segar telah lama digunakan sebagai obat herbal, namun bentuk teh daun sirsak kemasan belum banyak digunakan oleh masyarakat. Karena itu perlu dilakukan kajian tentang aktivitas antioksidan dalam teh daun sirsak, untuk menggali potensi daun sirsak sebagai minuman fungsional yang dapat difungsikan antara lain sebagai obat herbal (Adri dan Wikanastri, 2013).

Penelitian yang dilakukan Adri dan wikanastri (2013), mengenai aktivitas antioksidan teh daun sirsak berdasarkan variasi lama pengeringan dilakukan dengan metode DPPH. Hasil penelitian menunjukkan bahwa semakin lama pengeringan, semakin tinggi aktivitas antioksidan Berdasarkan hal tersebut, maka peneliti tertarik untuk melakukan pemeriksaan senyawa flavonoid dan polifenol serta melakukan uji aktivitas antioksidan dari teh daun sirsak kemasan (Annona muricata Linn.) dengan menggunakan metode pemerangkapan DPPH.

\section{Metode Penelitian}

\subsection{Sampel}

Pengambilan sampel dilakukan secara purposif yaitu pengambilan sampel dengan pertimbangan khusus sehingga layak dijadikan sampel. Sampel yang digunakan adalah sampel teh daun sirsak kemasan (Annona muricata Linn.) sebanyak 3 merek kemasan yaitu K1, K2, dan K3 yang berasal dari toko obat Hasan AS Jalan Letkol Iskandar No. 18 Ilir Barat 2 Palembang Sumatera Selatan.

\subsection{Alat}

Alat-alat yang digunakan pada penelitian ini terdiri dari alat-alat gelas laboratorium, neraca analitik

(Boeco Germany), hot plate, vortex, spektrofotometer UV-Visible (Shimadzu UV-1800), dan stopwatch.

\subsection{Bahan}

Bahan-bahan kimia: 1,1-diphenyl-2-picrylhydrazyl (DPPH) metanol, amil alkohol, asam klorida (p), besi (III) klorida, serbuk magnesium (Mg). Bahan berkualitas teknis: Air suling 


\subsection{Pemeriksaan Senyawa flavonoid dan Polifenol}

\subsubsection{Pemeriksaan Senyawa Flavonoid}

Sebanyak $10 \mathrm{~g}$ serbuk simplisia ditambahkan $10 \mathrm{ml}$ air panas, dididihkan selama 5 menit dan disaring dalam keadaan panas, kedalam $5 \mathrm{ml}$ filtrat ditambahkan $0,1 \mathrm{~g}$ serbuk magnesium dan $1 \mathrm{ml}$ asam klorida pekat dan $2 \mathrm{ml}$ amil alkohol, dikocok dan dibiarkan memisah. Flavonoida positif jika terjadi warna merah atau kuning atau jingga pada lapisan amil alkohol (Farnsworth, 1966).

\subsubsection{Pemeriksaan Senyawa Polifenol}

$5 \mathrm{ml}$ minuman teh daun sirsak dimasukkan ke dalam tabung reaksi. Ditambahkan 5 tetes larutan $\mathrm{FeCl} 35 \%$ dan dikocok kuat. Terbentuknya warna biru kehitaman setelah penambahan $\mathrm{FeCl} 3$ 5\% menunjukkan adanya senyawa fenolik (Adri dan Wikanastri, 2013).

\subsection{Uji Aktivitas Antioksidan Metode DPPH}

Kemampuan sampel uji dalam meredam proses oksidasi radikal bebas DPPH dalam larutan metanol (sehingga terjadi perubahan warna DPPH dari ungu menjadi kuning) dengan nilai IC50 (konsentrasi sampel uji yang mampu meredam radikal bebas 50\%) sebagai parameter menentukan aktivitas antioksidan sampel (Molyneux, 2004).

\subsection{Pembuatan Larutan Induk Seduhan Teh Daun Sirsak}

ditimbang sebanyak $1 \mathrm{~g}$ sampel uji, ditambahkan $100 \mathrm{ml}$ air panas, kemudian diletakkan diatas hotplate, lalu didihkan (Adri dan Wikanastri, 2013).

\subsection{Pembuatan Seduhan Teh Daun Sirsak}

Larutan induk dipipet sebanyak 1,25 ml; $2,5 \mathrm{ml} ; 3,75 \mathrm{ml} ; 5 \mathrm{ml} ; 6,25 \mathrm{ml}$; dan 7,5 ml; kemudian dimasukkan ke dalam masing-masing labu tentukur $25 \mathrm{ml}$ (untuk mendapatkan konsentrasi 500 ppm, 1000 ppm, 1500 ppm, 2000 ppm, $2500 \mathrm{ppm}$, dan $3000 \mathrm{ppm}$ ), Seduhan teh daun sirsak dengan berbagai konsentrasi masing-masing dipipet sebanyak 0,5 ml dan ditambahkan $5 \mathrm{ml}$ larutan DPPH 0,5 mM dengan konsentrasi $40 \mathrm{ppm}$, dihomogenkan dengan vortex, sebagai kontrol digunakan larutan DPPH tanpa penambahan larutan uji. Selanjutnya larutan diukur dengan alat spektrofotometer UV-VIS pada panjang gelombang $516 \mathrm{~nm}$ dan operating time 60 menit.

\subsection{Analisis Persen Pemerangkapan Radikal Bebas DPPH}

Penentuan persen pemerangkapan radikal bebas dihitung dengan rumus sebagai berikut:

$$
\text { Aktivitas pemerangkapan radikal bebas }(\%)=\frac{A \text { kontrol-A sampel }}{A \text { Kontrol }} \times 100 \%
$$

Keterangan : $\mathrm{A}_{\mathrm{kontrol}}=$ Absorbansi tidak mengandung sampel

$\mathrm{A}_{\text {sampel }}=$ Absorbansi sampel (Rosidah, et al, 2008;Marinova, 2011). 


\subsection{Analisis Nilai $I C_{50}$}

Perhitungan yang digunakan dalam penentuan aktivitas pemerangkapan radikal bebas adalah nilai IC50 (Inhibitory Concentration), nilai tersebut menggambarkan besarnya konsentrasi senyawa uji yang dapat memerangkap radikal bebas sebesar 50\% (Molyneux, 2004). Hasil perhitungan dimasukkan ke dalam persamaan regresi dengan konsentrasi sampel $(\mu \mathrm{g} / \mathrm{ml})$ sebagai absis (sumbu $\mathrm{x}$ ) dan nilai \% pemerangkapan (antioksidan) sebagai ordinatnya (sumbu y). Secara spesifik, suatu senyawa dikatakan sebagai antioksidan sangat kuat jika nilai IC50 kurang dari 50 ppm, kuat untuk IC50 bernilai 50-100 ppm, sedang jika IC50 bernilai 101-150 ppm dan lemah jika IC50 bernilai lebih dari 150 ppm (Fidrianny, et al.,2014).

\section{Hasil dan Pembahasan}

\subsection{Hasil Pengujian Aktivitas Antioksidan}

Tabel 1 Hasil pemeriksaan senyawa Flavonoid dan Polifenol seduhan teh daun sirsak pada masing- masing kemasan

\begin{tabular}{ccc}
\hline \multirow{2}{*}{ Sampel } & & Identifikasi \\
\cline { 2 - 3 } & Flavonoid & Senyawa Fenolik \\
\hline K1 & + & + \\
K2 & + & + \\
K3 & + & + \\
\hline
\end{tabular}

Keterangan : (+) Positif : mengandung golongan senyawa

(-) Negatif : tidak mengandung golongan senyawa

\subsection{Hasil Pemeriksaan Senyawa Flavonoid dan Polifenol}

Aktivitas antioksidan larutan uji masing-masing teh daun sirsak kemasan diperoleh dari hasil pengukuran absorbansi DPPH pada menit ke-60 dengan adanya penambahan larutan uji dengan konsentrasi 500 ppm, 1000 ppm, 1500 ppm, 2000 ppm, 2500 ppm, dan 3000 ppm yang dibandingkan dengan kontrol DPPH (tanpa penambahan larutan uji). Pada hasil analisis aktivitas antioksidan terlihat adanya penurunan nilai absorbansi DPPH sebanding dengan peningkatan konsentrasi masing-masing STDSK.

Penurunan absorbansi DPPH dan persen pemerangkapan dengan penambahan masing-masing STDSK dapat dilihat pada tabel berikut ini:

Tabel 2. Tabel hasil uji aktivitas antioksidan STDSK K1

\begin{tabular}{|c|c|c|c|c|c|c|c|c|}
\hline \multirow{2}{*}{$\begin{array}{l}\text { Larutan } \\
\text { Uji }\end{array}$} & \multirow{2}{*}{$\begin{array}{l}\text { Konsentrasi } \\
(\mathrm{ppm})\end{array}$} & \multirow{2}{*}{ I } & \multirow{2}{*}{$\begin{array}{l}\text { Absorbansi } \\
\text { II }\end{array}$} & \multirow{2}{*}{ III } & \multirow{2}{*}{ I } & \multicolumn{2}{|c|}{$\%$ Pemerangkapan } & \multirow{2}{*}{$\begin{array}{l}\text { Rata- } \\
\text { rata }\end{array}$} \\
\hline & & & & & & II & III & \\
\hline \multirow[t]{7}{*}{ K1 } & Blanko & 0,846 & 0,844 & 0,847 & 0 & 0 & 0 & 0 \\
\hline & 500 & 0,736 & 0,731 & 0,742 & 13,00 & 13,39 & 12,40 & 12,93 \\
\hline & 1000 & 0,614 & 0,610 & 0,618 & 27,42 & 27,73 & 27,04 & 27,40 \\
\hline & 1500 & 0,509 & 0,510 & 0,508 & 33,70 & 39,57 & 40,02 & 37,76 \\
\hline & 2000 & 0,399 & 0,400 & 0,398 & 44,70 & 52,61 & 53,01 & 50,12 \\
\hline & 2500 & 0267 & 0,270 & 0,263 & 68,44 & 68,01 & 68,95 & 68,47 \\
\hline & 3000 & 0,169 & 0,166 & 0,172 & 80.02 & 80.33 & 79.69 & 80.01 \\
\hline
\end{tabular}


Tabel 3. Tabel hasil uji aktivitas antioksidan STDSK K2

\begin{tabular}{|c|c|c|c|c|c|c|c|c|}
\hline \multirow{2}{*}{$\begin{array}{l}\text { Larutan } \\
\text { Uji }\end{array}$} & \multirow{2}{*}{$\begin{array}{l}\text { Konsentrasi } \\
(\mathrm{ppm})\end{array}$} & \multirow{2}{*}{ I } & \multirow{2}{*}{$\begin{array}{l}\text { Absorbansi } \\
\text { II }\end{array}$} & \multirow{2}{*}{ III } & \multirow{2}{*}{ I } & \multicolumn{2}{|c|}{ \% Pemerangkapan } & \multirow{2}{*}{$\begin{array}{l}\text { Rata- } \\
\text { rata }\end{array}$} \\
\hline & & & & & & II & III & \\
\hline \multirow[t]{7}{*}{$\mathrm{K} 2$} & Blanko & 0,846 & 0,844 & 0,847 & 0 & 0 & 0 & 0 \\
\hline & 500 & 0,736 & 0,731 & 0,742 & 13,00 & 13,39 & 12,40 & 12,93 \\
\hline & 1000 & 0,614 & 0,610 & 0,618 & 27,42 & 27,73 & 27,04 & 27,40 \\
\hline & 1500 & 0,509 & 0,510 & 0,508 & 33,70 & 39,57 & 40,02 & 37,76 \\
\hline & 2000 & 0,399 & 0,400 & 0,398 & 44,70 & 52,61 & 53,01 & 50,12 \\
\hline & 2500 & 0267 & 0,270 & 0,263 & 68,44 & 68,01 & 68,95 & 68,47 \\
\hline & 3000 & 0,169 & 0,166 & 0,172 & 80.02 & 80.33 & 79.69 & 80.01 \\
\hline
\end{tabular}

Tabel 4. Tabel hasil uji aktivitas antioksidan STDSK K3

\begin{tabular}{|c|c|c|c|c|c|c|c|c|c|}
\hline \multirow{2}{*}{$\begin{array}{l}\text { Larutan } \\
\text { Uji }\end{array}$} & \multirow{2}{*}{$\begin{array}{l}\text { Konsentras } \\
(\mathrm{ppm})\end{array}$} & \multicolumn{4}{|c|}{ Absorbansi } & \multicolumn{2}{|c|}{ \% Pemerangkapan } & \multirow[b]{2}{*}{ III } & \multirow[b]{2}{*}{ Rata-rata } \\
\hline & & I & & & III & I & II & & \\
\hline \multirow[t]{7}{*}{ K3 } & Blanko & 0,802 & 0,803 & 0,805 & & 0 & 0 & 0 & 0 \\
\hline & 500 & 0,729 & 0,724 & 0,720 & & 9,10 & 9,84 & 10,56 & 9,83 \\
\hline & 1000 & 0,628 & 0,638 & 0,648 & & 21,70 & 20,55 & 19,50 & 20,58 \\
\hline & 1500 & 0,541 & 0,550 & 0,564 & & 32,54 & 31,51 & 29,93 & 31,32 \\
\hline & 2000 & 0,480 & 0,477 & 0,474 & & 40,15 & 40,60 & 41,11 & 40,62 \\
\hline & 2500 & 0,380 & 0,370 & 0,360 & & 52,61 & 53,92 & 55,28 & 53,93 \\
\hline & 3000 & 0,279 & 0,284 & 0,289 & & 65,21 & 64,63 & 64,09 & 64,64 \\
\hline
\end{tabular}

Penurunan nilai absorbansi menunjukkan peningkatan aktivitas antioksidan. Penurunan nilai absorbansi terjadi karena STDSK mampu menetralisir DPPH dengan memberikan elektron kepada DPPH sehingga atom dengan elektron yang tidak berpasangan mendapat pasangan elektron dan tidak lagi menjadi radikal (Silalahi, 2006), hal ini ditandai dengan warna larutan yang berubah dari ungu tua menjadi kuning terang dan absorbansi pada panjang gelombang maksimumnya menurun (Molyneux, 2004). Hubungan antara konsentrasi dengan persen pemerangkapan radikal bebas DPPH oleh masing-masing STDSK dapat dilihat pada gambar berikut ini:

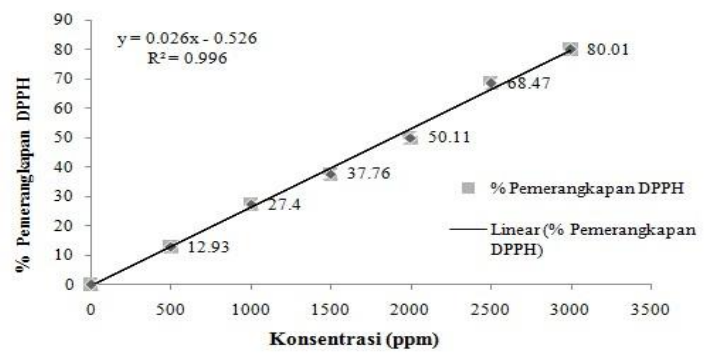

Gambar 1. Grafik Hasil Uji Aktivitas Antioksidan STDSK K1

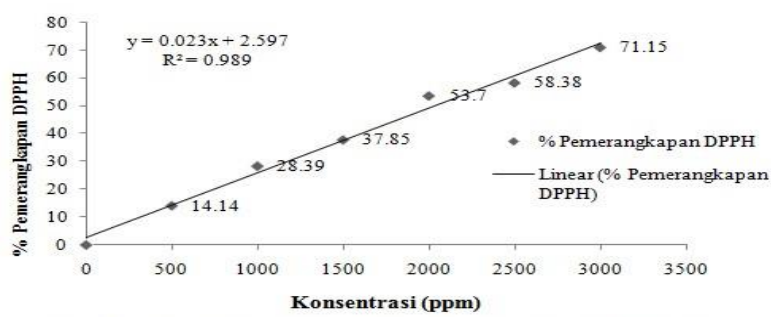

Gambar 2. Grafik Hasil Uji Aktivitas Antioksidan STDSK K2 


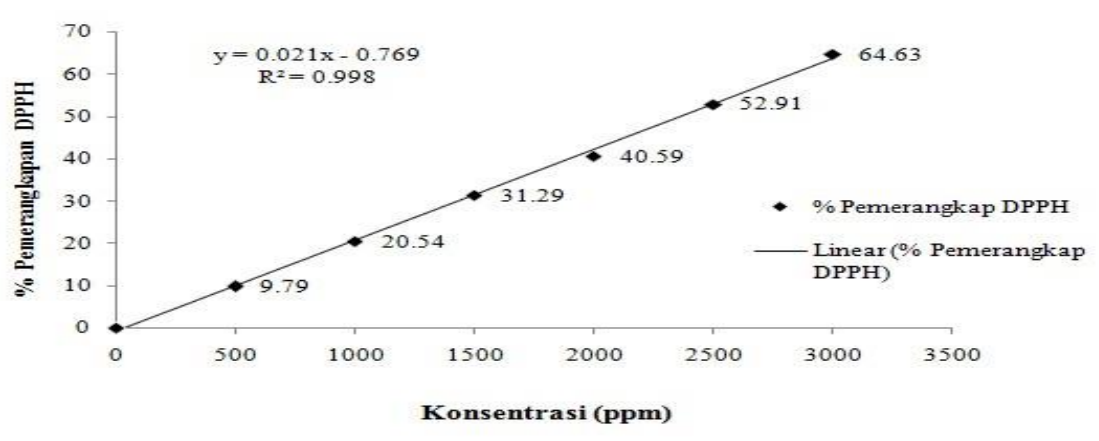

Gambar 3. Grafik Hasil Uji Aktivitas Antioksidan STDSK K3

Dari Tabel 2 dan juga pada gambar grafik 1,2 dan 3 di atas, dapat dilihat penurunan nilai absorbansi menunjukkan peningkatan aktivitas antioksidan. Penurunan nilai absorbansi terjadi karena STDSK mampu menetralisir DPPH dengan memberikan elektron kepada DPPH sehingga atom dengan elektron yang tidak berpasangan mendapat pasangan elektron dan tidak lagi menjadi radikal (Silalahi, 2006), hal ini ditandai dengan warna larutan yang berubah dari ungu tua menjadi kuning terang dan absorbansi pada panjang gelombang maksimumnya menurun (Molyneux, 2004).

Tabel 5. Hasil persamaan regresi linier dan hasil analisis $\mathrm{IC}_{50}$ yang diperoleh dari masing masing kemasan.

\begin{tabular}{lll}
\hline Larutan Uji & Persamaan regresi & $\mathrm{IC}_{50}(\mathrm{ppm})$ \\
\hline STDSK K1 & $\mathrm{y}=0,027 \mathrm{x}-0,301$ & 1943 \\
STDSK K2 & $\mathrm{y}=0,023 \mathrm{x}+1,978$ & 2287 \\
STDSK K3 & $\mathrm{y}=0,021 \mathrm{x}-0,769$ & 2383 \\
\hline
\end{tabular}

Dari tabel 5 menunjukkan aktivitas antioksidan STDSK masing-masing kemasan dalam kategori sangat lemah dengan nilai $\mathrm{IC}_{50} \mathrm{~K} 1$ sebesar 1943 ppm, K2 sebesar 2287 ppm, dan K3 sebesar 2383 ppm. Menurut Ridho (2013) senyawa flavonoid dan polifenol masih berikatan dengan gugus glikosida karena gugus glikosida yang berikatan dengan senyawa tersebut dapat menurunkan aktivitas antioksidan.

\section{Kesimpulan Dan Saran}

\subsection{Kesimpulan}

Berdasarkan hasil penelitian yang telah dilakukan dapat disimpulkan:

- Hasil pemeriksaan golongan senyawa flavonoid dan polifenol sediaan teh daun sirsak kemasan menunjukkan adanya kandungan golongan senyawa yang memiliki aktivitas sebagai antioksidan.

- Hasil analisis antioksidan menunjukkan bahwa masing-masing STDSK memiliki aktivitas antioksidan dan nilai IC $_{50}$ masing-masing STDSK adalah K1 sebesar 1943 ppm, K2 sebesar 2287 ppm, dan K3 sebesar 2383 ppm dan termasuk dalam kategori sangat lemah.

\subsection{Saran}

Disarankan kepada peneliti selanjutnya untuk melakukan pengujian aktivitas antioksidan dari seduhan daun sirsak kemasan menggunakan metode pemerangkapan DPPH berdasarkan variasi lama perebusan. 


\section{Daftar Pustaka}

[1] Adri, Delvi Dan Wikanastri Hesolisstyiorini. 2013. Aktivitas Antioksidan dan Sifat Organoleptik Teh Daun Sirsak ( Annona Muricata Linn ) Berdasarkan Variasi Lama Pengeringan. Jurusan Teknologi Pangan. Fakultas Pertanian. Universitas Muhammadiyah Semarang. Semarang. Vol. 04 No 7 Tahun 2013.

[2] Budiarti, A. et al., (2014). Aktivitas Antioksidan Fraksi Kloroform Ekstrak Etanol Daun Sirsak (Annona muricata L.) dan Identifikasi kandungan Senyawa Kimianya. Jurusan Farmasi. Fakultas Farmasi. Universitas Wahid Hasyim Semarang. Prosiding SNST ke-5 Tahun 2014.

[3] Cook, N.C., Samman S., (1996). Flavonoids and Chemistry, Metabolism, Cardioprotective Effect, and Dietary Sources, Journal of Nutritional Biochemistry, 7 ; 66-67.

[4] Farnsworth, N. R. (1966). Biological and Phytochemical Screening of Plants. Journal of Pharmaceutical Sciences. 55(3): $263-264$.

[5] Fidrianny, I., Darmawati, A dan Sukrasno. (2014). Antioxidant Capacities from Different Polarities Extracs of Cucurbitaceae leaves Using FRAP, DPPH Assay and Correlation with Phenolic, Flavonoid, Carotenoid Content. International Journal of Pharmacy and Pharmaceutical Sciences. 6(2): 858-862.

[6] Handayani, H. Et al., (2016). Ekstraksi Antioksidan Daun Sirsak Metode Ultrasonic Bath (Kajian Rasio: Pelarut dan Lama Ekstraksi). Jurusan Teknologi Hasil Pertanian, Universitas Brawijaya, Malang. Jurnal Pangan dan Agroindustri vol. 4 No. 1 p.262-272.

[7] Hernani. (2005). Tanaman Berkhasiat Antioksidan. Depok: Penebar swadaya.

[8] Julyasih, K.S.M., Wirawan, I.G.P., Harijani W.S., dan Widajati W. 2009. Aktivitas Antioksidan Beberapa Jenis Rumput Laut (Seaweeds) Komersial Di Bali. Seminar Nasional, Akselerasi Pengembangan Teknologi Pertanian Dalam Mendukung Revitalisasi Pertanian, Fakultas Pertanian \& LPPM UPN Veteran Jawa Timur.

[9] Marinova, G. dan Batchvarov, V. (2011). Evaluation of the Methods for Determination of the Free Radical Scavenging Activity by DPPH. Bulg. J. Agric. Sci. 17: 13-14.

[10] Molyneux, P. (2004). The Use of the Stable Free Radical Diphenylpicrylhydrazyl (DPPH) for Estimating Antioxidant Activity. Songklanakarin J. Sci. Technol. 26(2): 211-219.

[11] Nordmann, R., (1993). Free Radicals, Oxidative Stress, and Antioxidant Vitamins, CR Sciences Soc. Biol. Fill., $277-285$.

[12] Ridho, E.A., et al., (2013). Uji Aktivitas Antioksidan Ekstrak Metanol Buah Lakum Dengan Metode DPPH. Program Studi Farmasi Fakultas Kedokteran, Universitas Tanjung Pura.

[13] Rosidah, Yam, M.F., Sadikun, A., dan Asmawi, M.Z. (2008). Antioxidant Potential of Gynura procumbens. Pharmaceutical Biology. 46(9): 616-625.

[14] Salamah, N dan Erlinda W., (2015). Aktivitas Antioksidan Ekstrak Metanol Daun Kelengkeng Dengan Metode DPPH. Fakultas Farmasi Universitas Ahmad Dahlan, Yogyakarta. Pharmaciana, vol 5, No. 1, 2015: 25-34

[15] Silalahi, J. (2006). Makanan Fungsional. Yogyakarta: Kanisius.

[16] Winarsi, H. (2007). Antioksidan Alami dan Radikal Bebas. Yogyakarta: Kanisius.

[17] Werdhasari, A. (2014). Peran Antioksidan bagi Kesehatan. Pusat Biomedis dan Teknologi Dasar Kesehatan Balitbangkes, Kemenkes RI 